OPEN ACCESS

\title{
Germany Goes Green - Innovations towards a Sustainable Regional Development
}

\author{
Dietwald Gruehn
}

School of Spatial Planning, Dortmund University of Technology, Germany / School of Planning, Design \& Construction, Michigan State University, USA

\begin{abstract}
The paper deals with recent paradigm shift in German environmental policy, fundamentally modifying the German society towards a sustainable future development. Key elements of this development are forceful climate protection measures to contribute to global climate protection strategy and to fulfil international conventions, supplemented by a comprehensive strategy to promote the adaptation to climate change, the nuclear power phase out in the medium term, and innovative landscape and regional planning projects to strengthen regional identity and economic power. All this components are,complemented by a financial support program including incentives, tax reductions, and research funding.
\end{abstract}

Keywords : Climate change, Renewable energy, Nuclear phase out, Landscape and Regional planning, Environmental economy

\section{INTRODUCTION}

This paper reflects the recent development and outcome of environmental policy in Germany and highlights the consequential process during the last few decades. Environmental policy in Germany to an increasing extent has proved to be cross-sectoral and interdisciplinary, which requires new organization forms in the mostly traditional world of administration towards more co-operation, networks and crosssectoral agreements by turning away classical hierarchical structures, what might be a challenge in administrative life.

Besides, from a theoretical point of view the complexity of the societal system with it's cultural, social, political, environmental, economic, technical and juridical requirements and potentials is demanding innovative approaches rather than

*Correspondence to : Prof. Dietwald Gruehn

Prof. Landscape Ecology and Landscape Planning, School of Spatial Planning, Dortmund University of Technology, Germany / Adjunct Professor of Urban and Regional Planning, School of Planning, Design \& Construction, Michigan State University, USA

E-mail : dietwald.gruehn@udo.edu

World Technopolis Review

Copyright $\odot$ World Technopolis Association

CC This is an open-access article distributed under the terms of the Creative Common Attribution Non-Commercial License(http://creativecommons.org/licenses/by-nc/3.0) which permits unrestricted noncommercial use, distribution, and reproduction in any medium, provided the original work is properly cited traditional ones (Weber and Hemmelskamp 2005).

Environmental Policy in Germany has a long tradition, starting in the beginning of the 1970s on the basis of a governmental initiative of the first social-democratic and liberal coalition in the Federal Republic of Germany. The starting point was the "Environmental Program of the Federal Government" which has been described as environmental action plan, initializing more than 100 laws and by-laws (Simonis 2001). Policies or initiatives concerning environmental issues before 1970 were oriented more sectoral, such as an area wide introduction of wastewater treatment plants and therefore are not discussed in detail, here. During the 1970s, landscape planning was legally implemented on several administrative levels as a comprehensive instrument to sustainably ensure a broad range of ecosystem services, including habitat functions for flora and fauna, landscape scenery, biotic production, groundwater recharge, biometeorological functions etc. (Gruehn 2006).

Further progress in German environmental policy was induced by shock news in the papers as described below. The first occurrence was the phenomenon of forest decline, also known as "Waldsterben," beginning in the 1980s (Ulrich 1995), which induced a voluminous national research funding program on ecosystem research, including policy 
options to counter the observed trends. Another effect of the forest dieback was that at least those Germans, who were entitled to vote, became more and more sensitive to environmental concerns, which was accompanied by the emergence and a rapidly increasing popularity of the new green party.

The second event was the Chernobyl disaster in 1986, which lead to a continuing rise of sensitivity to environmental issues on the one hand (Köcher 2011) and to an establishment of the first (independent) federal environmental ministry in Germany in 1987 on the other hand. During this decade the first federal state government involving the green party was constituted, namely in the Federal State of Hesse.

After the German reunification in 1990 the conservative and liberal federal government successfully launched a liberalization policy, accelerating planning and decision making procedures at cost of environmental concerns and public participation. This was motivated by a strategy to reconvert East Germany, which was ruined under socialistic sovereignty, to a "flourishing" landscape under the new conditions of market economy(Stolte 2010). Parallel to this global climate change became a severe problem, not only recognized by scientists, but increasingly perceived by politicians and other decision makers, too. With the adoption of the Kyoto Protocol a worldwide majority of states committed themselves to a mandatory reduction of green house gases, including Germany (United Nations 1998).

In addition to this, the European Union (EU, EC or EEC) to an increasing extent created environmental regulations, such as Environmental Impact Assessment Directive (EEC 1985), Habitats Directive (EEC 1992), Water Framework Directive (EC 2000), and Strategic Environmental Assessment Directive (EC 2001).

Another crucial turning point in environmental policy in Germany was the replacement of the conservative and liberal coalition by a new federal government in 1998, which at the first time was established by social democratic and green party. Since the majority of green party members were recruited from the anti-nuclear movement of the 1970s, the new government in the year 2000 heralded a nuclear phaseout in Germany with a 32 years perspective. This policy was accompanied by a fundamental support of renewable energies in terms of research activities as well as a creation of incentives (Egle, Ostheim and Zohlnhöfer 2003).

Though the current German federal government, consisting again of conservative and liberal party has partly retract- ed the nuclear power phase out in 2010, the Fukushima Daiichi nuclear disaster in 2011 was reason for a fundamental environmental policy paradigm shift of conservative and liberal party in Germany, which agreed to a (second) nuclear power phase out in 2011, supported by the majority of the public. Unlike in 2000, the time frame of the new agreement is only 11 years (GFME 2012a).

\section{Climate CHANGE}

\subsection{Climate Protection}

Climate change refers to a change in the state of the climate that can be identified (e.g. using statistical tests) by changes in the mean and/or the variability of its properties, and that persists for an extended period, typically decades or longer. It refers to any change in climate over time, whether due to natural variability or as a result of human activity (IPCC 2007). One important, but not the only aspect of climate change is the global warming, observed in the last 5 decades, mainly caused by greenhouse gas emissions. Between 1970 and 2004 there was an increase of global annual emissions of anthropogenic greenhouse gases more than $70 \%$. In the same period the increase of carbon dioxide $\left(\mathrm{CO}_{2}\right)$ emissions was about $80 \%$. The major fraction of greenhouse gases derive from $\mathrm{CO}_{2}$ emissions from fossil fuels, smaller proportions stem from $\mathrm{CO}_{2}$ emissions, caused by deforestation, decay and peat, from methane $\left(\mathrm{CH}_{4}\right)$ emissions from agriculture, waste and energy as well as from nitrous oxide $\left(\mathrm{N}_{2} \mathrm{O}\right)$ from agriculture and others (IPCC 2007). Climate Protection is a policy focussing on the reduction of greenhouse gas emissions, whereas adaptation to climate change is policy, dealing with potential consequences of climate change on the societal system, including environmental, social and economic effects.

Since the Kyoto Protocol has come into effect, German government focused on climate protection to reach the national Kyoto target. This requires a reduction of greenhouse gas emissions from 1990 to 2010 by 20\%. Germany reached this goal in 2008, yet (Federal Environment Agency 2011) by implementing a new energy policy, especially supporting renewable energy, such as solar power, geothermal energy, wind power and bio energy. Another important group of measures was dedicated to reduce energy consumption, by introducing new low energy technologies in daily life. This comprises technologies in the housing sector, 


\section{Special Contribution}

such as low and zero energy houses or even energy plus houses for new development as well energy saving heating systems and windows as well as house insulation measures for existing buildings. An absolute innovation is that different sectoral policies, such as housing construction, research and development as well as the finance sector, including funding schemes and tax reduction, have been linked to an integrated policy. Further goals are the reduction of greenhouse gas emissions by $40 \%$ until 2020 , by $55 \%$ until 2040 , and by at least 80\% until 2050, compared to 1990 (GFME 2012a, Federal Environment Agency 2012).

\subsection{Adaptation to Climate Change}

Adaption to climate change was not regarded as highly relevant in Germany until about 2005. In that time the insight became accepted, that - despite of the enormous climate protection efforts of German government - the global warming would continue if international negotiations would not achieve a consensus among all countries of the world. Under these circumstances the country and its regions could be affected less or more intensive depending on the change of regional specific patterns of climate parameters. A crucial impact on the policy development in Germany was induced by striking research results on the regionalization of climate change impacts, which revealed a high variation of climate change parameters on the regional level (Gerstengarbe et al. 2003; Zebisch et al. 2005; PIK 2005).

The German Federal Government (2008) terminated a national adaptation strategy to cope with less or more likely problems resulting from climate change. The character of this strategy is highly integrative, addressing need for action in a broad range of fields comprising human health, civil engineering, water management, coastal protection, sea environmental protection, soil protection, biodiversity, agriculture, forestry and fishery, energy management, financial management, transport infrastructure, industry and business, tourism, and spatial, regional and urban planning. Furthermore the adaptation strategy contains first ideas, how Germany could support other countries in their consideration, whether or not, and if so, how to develop an adaptation strategy. This policy was complemented by the German Federal Ministry of Education and Research. This ministry first launched $\mathrm{a} € 35$ million research program which was followed by another $€ 75$ million program, both programs following the integrative approach of the government described above (Mahammadzadeh and Chrischilles 2012).

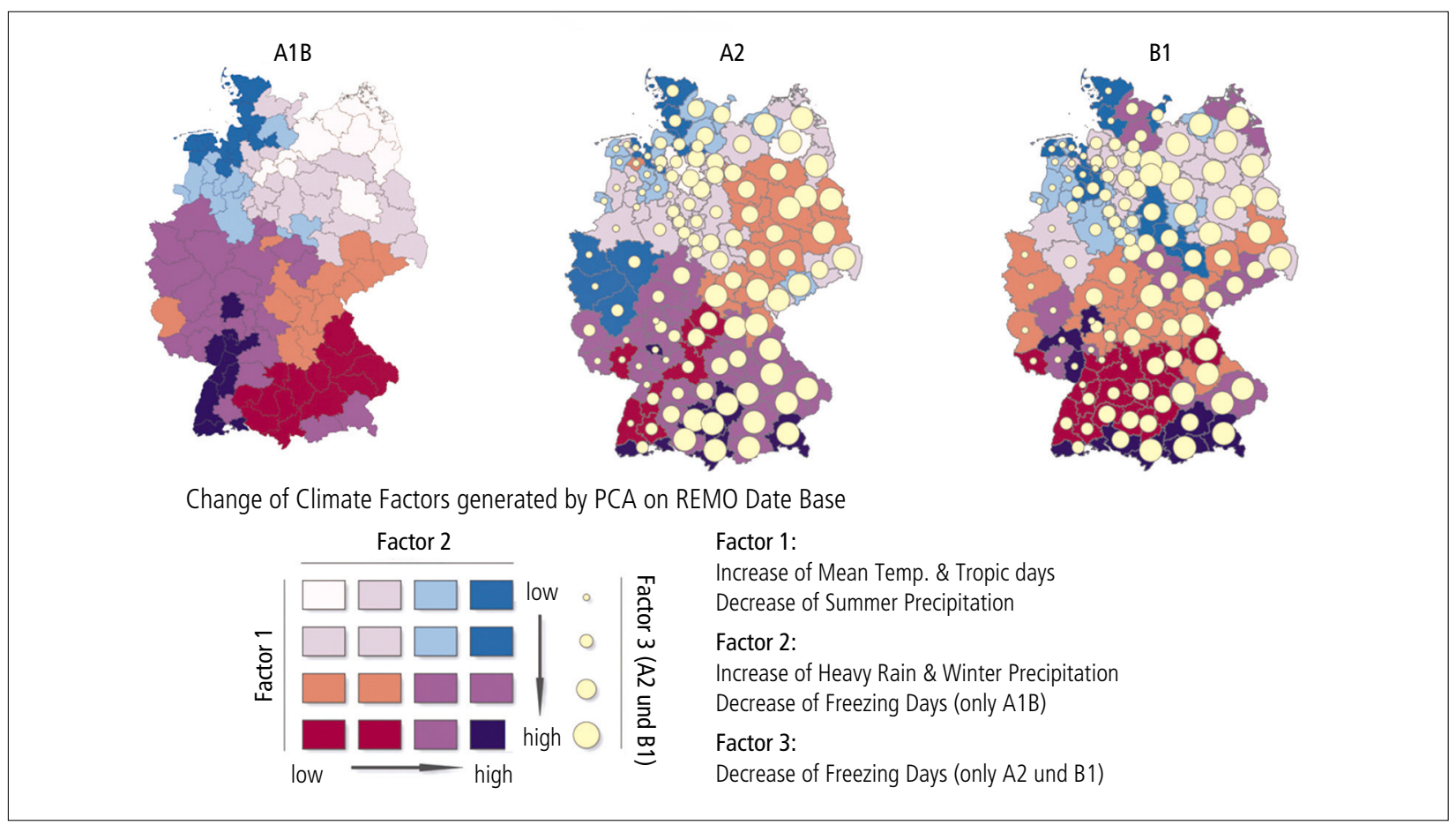

Fig. 1. Regional Types of Climate Change in Germany for the Period 2071-2100 (Gruehn 2008) 
his enables research organization from different scientific fields to found interdisciplinary consortiums, co-operating with regional decision makers and the public. Parallel to this the German Federal Ministry of Transport, Building and Urban Development launched a demonstration project of spatial planning focussing on spatial development strategies considering climate change (Rannow et al. 2010). Fig. 1 points out different scenarios concerning less or more likely changes of climate, depending on the IPCC-scenarios A1B, $\mathrm{A} 2$ and B1 (IPCC 2007). To reduce the complexity, seven climate parameters on REMO databasis (Jacob and Podzun 1997) were converted by means of principal component analysis (PCA) to 2 (scenario A1B) or 3 (scenario A2 and B1) factors representing 3 independent dimensions in the data set.

On this basis the following impacts, comprising slow changes and extreme events, have been identified, relevant for a solution within regional and urban planning instruments:

- Increased loss of soil by water erosion,

- Increased loss of species and biodiversity,

- More pronounced fluctuations of the ground water level,

- Increasing fluctuations in water availability for industrial use,

- Occurrence of longer and more intensive heat waves,

- Increasing frequency of heavy rains and flash floods,

- Increasing frequency of large river flood events,

- Increasing frequency and intensity of storm surges,

- Increasing frequency of mass movements (landslides etc.),

- Increasing frequency of forest fires,

- More frequent destruction of infrastructure.

The results of this demonstration project are being about to be substantiated within several implementation projects on the regional level aiming at creating regional partnerships of decision makers, authorities, stakeholders of the regional economy, and the general public.

The example of climate change points out how research, government, society and economy in Germany are interacting aiming at to create new knowledge, to disseminate this knowledge and to adapt it to regional and local conditions, and thereby creating fundamental innovations.

\section{ENERGY POLICY}

\subsection{Nuclear Phase Out}

As described above the Fukushima Daiichi nuclear disaster in 2011 fundamentally changed the majorities in the German parliament concerning future energy policy. While until 2011 only green and social democratic party voted for a nuclear power phase out of Germany, at this point conservative and liberal party were undergoing a fundamental paradigm shift, supported by the majority of the public: In 2011, only $3 \%$ of polled Germans preferred nuclear power plants as means of electricity generation in their neighbourhood, whereas a majority agreed with solar parks (76\%), renewable energy sites in general (65\%) or wind energy plants (60\%). The result was a final nuclear power phase out in 2011 with a time frame of only 11 years (GFME 2012a). Major reasons for this new consensus in Germany have been the insight that is impossible to reduce nuclear risks to an acceptable level, especially in densely populated countries. Additionally, the final deposition of nuclear waste in Germany is still unsolved, although many potential locations have been investigated, during the last four decades. And, finally, Uranium sources are limited, for which reason increasing commodity prices are expected. Eight nuclear power plants in Germany have been closed down, from which seven plants were cut-off immediately after the Fukushima Daiichi nuclear disaster in March 2011. The remaining 9 nuclear power plants will be stepwise closed down until 2022 (GFME 2012 a).

\subsection{Promotion of Renewable Energy}

Climate protection necessarily requires a reduction of greenhouse gas emissions. Therefore some countries are aiming at to extend the use of nuclear power, because the generation of electricity by nuclear power plants does not contribute to $\mathrm{CO}_{2}$-emissions. The German policy aiming at to replace non-renewable by renewable energies is very ambitious, because of the contemporaneous nuclear phase out. Thus, because of safety reasons nuclear power in Germany will not be used longer than 2022. That means in turn, that nuclear power can not be used as transition technology after 2022 to replace coal, gas and oil in the mid term. To fulfil future international greenhouse gas reduction targets the replacement of non-renewable by renewable energies has to be accelerated. This needs a concerted action of further research, a rapid information transfer into the production sector, and high acceptance of the renewable energies especially among decision makers and investors.

Fig. 2 points out the increasing share of renewable energies in electricity generation, heat supply, fuel consumption, and total energy consumption in Germany during the time 


\section{Special Contribution}

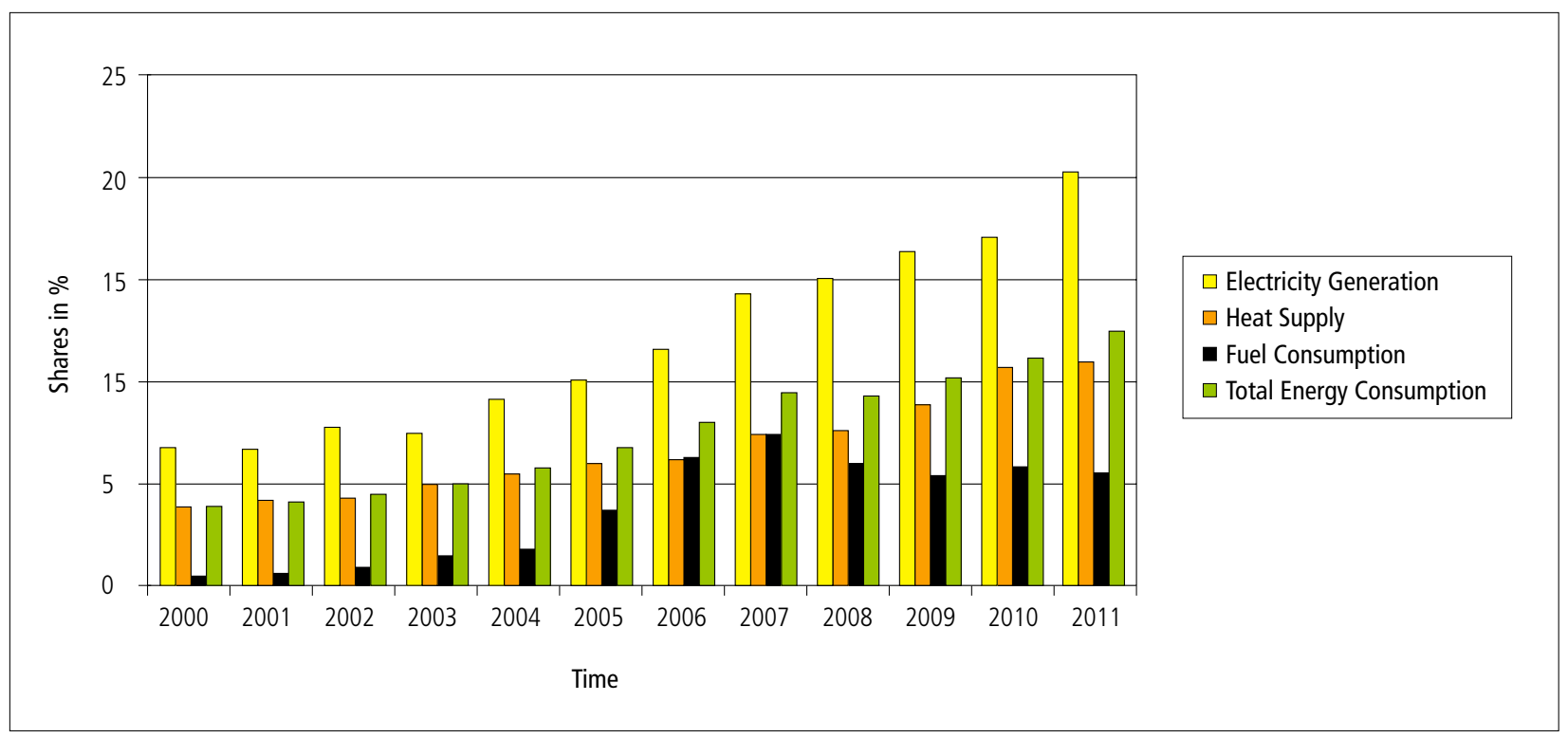

Fig. 2. Shares of renewable energies in electricity generation, heat supply, fuel consumption, and total energy consumption in Germany from 2000 to 2011 (GFME 2012b)

span from 2000 to 2011. Renewable energies meanwhile (2011) cover a portion of $20.3 \%$ of the electricity generation, $11 \%$ of heat supply, and $5.5 \%$ of fuel consumption. The total energy consumption in Germany in 2011 was covered 12.5\% by renewable energies, generated from water, wind, biomass, solar, and geothermal power (GFME 2012b). It is proposed to increase the share of renewables in electricity consumption to $50 \%$ in 2030 or $80 \%$ in 2050 , respectively. The renewable energy shares are intended to be increased to $30 \%$ in 2030 and 60\% in 2050 (GFME 2012b). To ensure acceptance of renewable energies and to promote them at the same time, German government has created a broad range of incentives, credits at a reduced price or tax reduction on investment. This makes investments in renewable energies profitable, especially in recession times. For instance an installation of photovoltaic panels on a house roof in 2011 generated a return on investment of about $8-10 \%$.

\subsection{Additional Measures}

The replacement of nuclear power and non-renewable energy by renewables requires several additional measures. The first approach is focused on energy saving. From 1990 to 2011 the mean energy consumption per capita in Germany has decreased from 187 to 163 GJ. This approximates a reduction of $13 \%$. Energy consumption in relation to the gross domestic product has decreased in Germany from 8.3
GJ per $€ 1,000$ (1990) to 5.5 GJ per $€ 1,000$ (2011), which is a reduction of $34 \%$ (AGEB 2012). The reduction of energy consumption could be realized by an increased efficiency in the industry, traffic, and housing sector. In the housing sector much effort was put on the development of low and zero energy houses or even energy plus houses, accompanied by the development of new windows and energy saving heating systems, including solar power, geothermal energy etc., which are also suitable for older houses. For existing buildings specific insulation technologies have been developed, which leads to huge savings, especially for houses, which have been built between 1950 and 1975 (GFME 2012a/b).

Another field of research and development is focused on new saving technologies, such as lithium-ion-batteries and thermo chemical energy savers. Finally, the new energy policy makes an extension of energy infrastructure necessary. The task of the national development plan for the electric power system is to expand the existing network of high voltage power lines (NEP 2012). It is likely, that this will lead to visual impairments of traditional cultural landscapes in Germany (Roth and Gruehn 2012). To optimize the planning procedure for the electric power system, recommendations of landscape planning instruments, based on a sound visual landscape assessment, should be considered in the decision making process. 


\section{LANDSCAPE AND REGIONAL PLANNING}

The innovations in Germany towards a sustainable development are not limited to technological aspects, such as energy generation or energy saving. Since decades, spatial planning instruments support a future oriented long term development by defining sustainable and climate proof land use structures, including ecological and aesthetical dimension, and by providing concepts how to implement the required changes. Below, two single of hundreds of interesting projects are highlighted to give evidence of the promotion of green development in Germany by landscape and regional planning.

\subsection{Revitalization Projects in Agglomerations}

Since the claiming of soil for development and infrastructure projects in most German cities is still proceeding at the cost of green spaces, agricultural and sometimes even forest land use, more and more cities tend to rethink this practice and are striving for revitalization of formerly used areas for new purposes, especially in the Ruhr area in the western part of Germany (Uttke et al. 2008).

One of the most outstanding revitalization projects in Germany is the Emscher renaturation, which is a paradigm for the new trend of taking into account challenges of sustainability as well as climate change into urban development. This project is focussed on the renaturation of the $80 \mathrm{~km}$ long Emscher river, which has been used as sewer for more than hundred years. The $€ 5$ billion project aims at establishing a huge landscape park instead of the old open sewer system. Emscher landscape park will comprise cooling green spaces, areas for flood control, recreation areas and habitat network and therefore enhance life quality in Ruhr metropolitan area, especially under future climate conditions (Gruehn 2010). Fig. 3 points out how the Emscher water course has changed after the renaturation during the last couple of years. The efforts which have been undertaken in the Ruhr region in the last decades did not only contribute to the structural change in terms of economics but also to a positive mental change how people perceive the region.

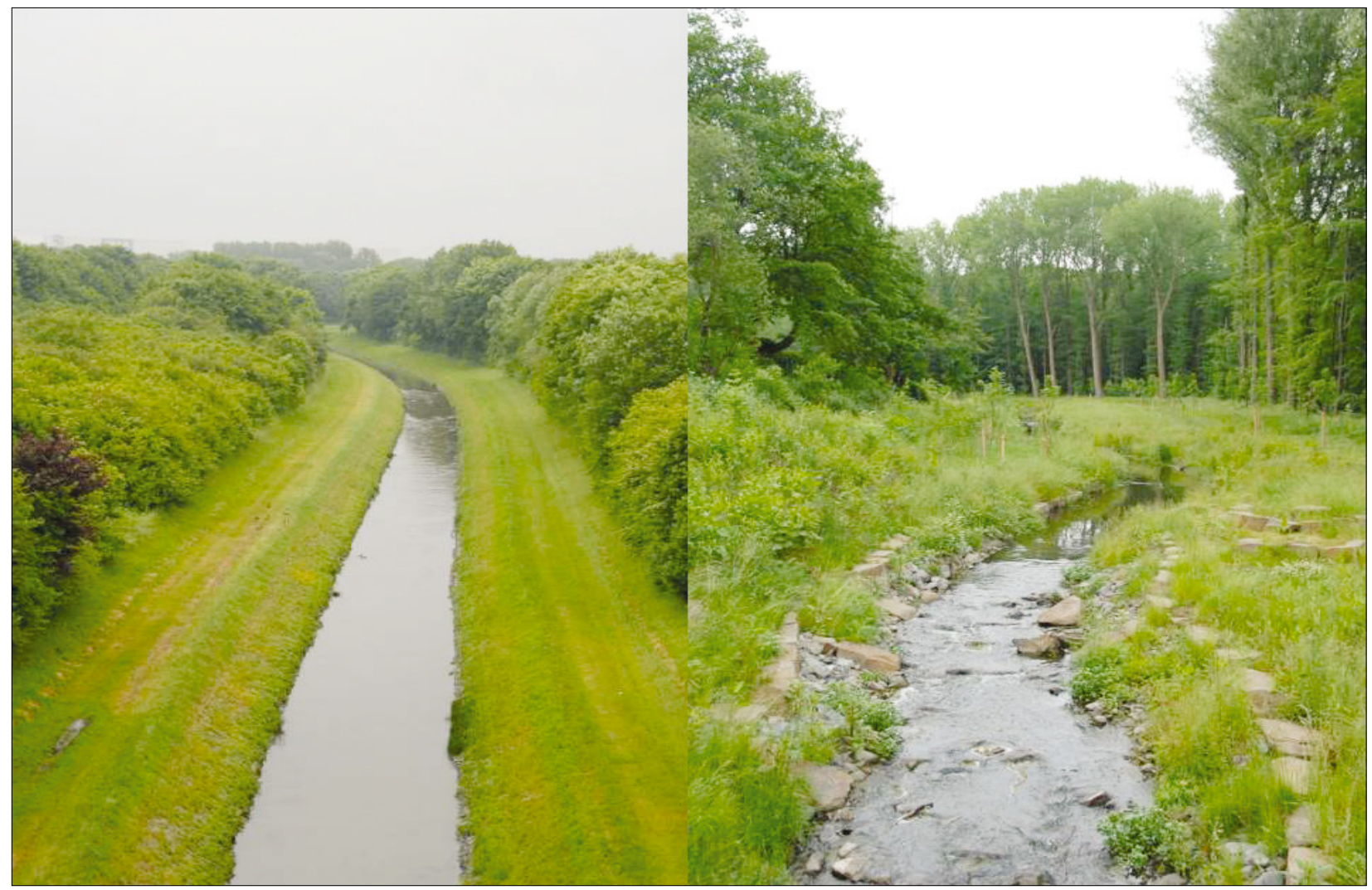

Fig. 3. Emscher river before (left) and after (right) its renaturation in the city of Dortmund (Photos: Gruehn 2012) 


\section{Special Contribution}

\subsection{The German Green Belt Becomes European}

Another innovative project is the German green belt (Fig. 4 ), which takes course along the former boundary between the Federal Republic of Germany (West-Germany) and the German Democratic Republic (East Germany).

Since 1990 the former German border has naturally developed to a habitat. Key challenge in those times was to protect or at least to keep the area free from other demands, such as housing, agriculture or forestry use. Hence, the former "iron curtain" has become both a cultural monument with regard to the European, especially the German history, as well as an important habitat, e.g. for lynxes and rare bats.

In 2003 the German Federal Agency for Nature Conservation has initiated to expand the German green belt to a European green belt, starting from the Norwegian/Russian border, connecting the German green belt and continuing to the Greek/Turkish border. Because of the interest of Korean stakeholders in the German green belt, in 2012 the German Federal Agency for Nature Conservation has made an agreement with the Korean province of Gyeonggi to exchange information and to promote ideas for a future natural development of the Korean demilitarized zone (GFME and FAN 2012).

\section{ECONOMIC ASPECTS OF ENVIRONMENTAL POLICY}

Adaptation to climate change, the change of the energy policy, but also green projects, such as the Emscher revitalization may have considerable economic impacts, which have not been calculated in total, yet. Although there have been published studies on partial economic effects of certain policies, strategies or measures. They indicate the economic significance of today's environmental policy in Germany.

The production share of environmental protection goods in relation to all industrial products has increased in Germany from 4.7\% in 2002 to $5.7 \%$ in 2009. From 1993 to 2009 the global share of exported German environmental goods was nearly constant, whereas the export from other countries, such as United States, Japan, United Kingdom and France less or more dramatically dropped (Schasse, Gehrke and Ostertag 2012). It has been estimated that the number of newly created jobs in Germany in the renewable energy sector was more than 200,000, starting from 160,500 in 2004 to about 367,400 in 2010 (Federal Environment Agency 2012). In 2010 the expenditure for renewable energy plants in Germany was about $€ 27$ billion (GFME 2011).

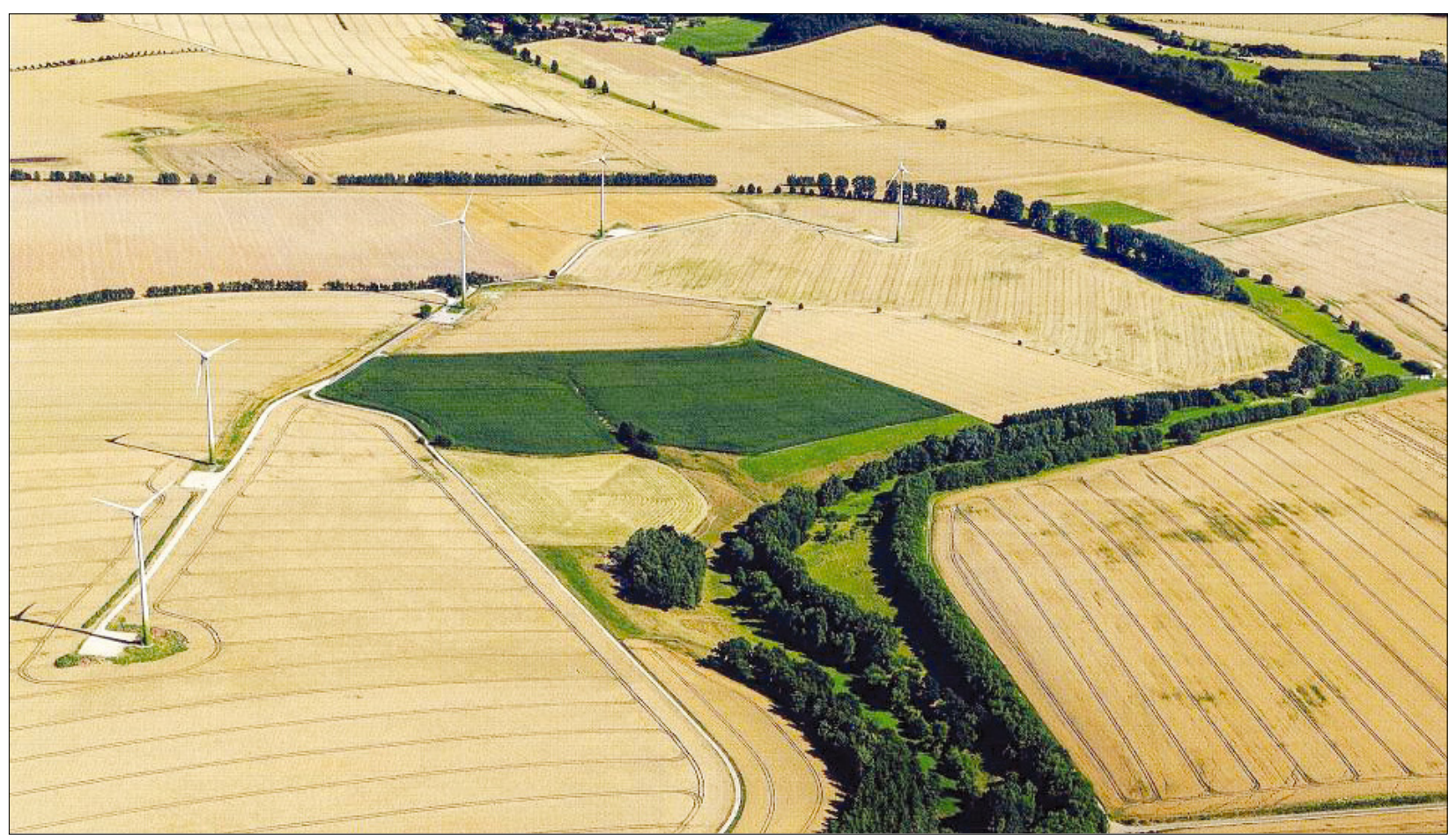

Fig. 4. The German Green Belt (Photo: GFME \& FAN 2012) 
Finally, recent investigations reveal that urban open spaces have a considerable economic effect on land values in large and medium-sized German cities (Budinger and Gruehn 2012).

\section{CONCLUSION}

Germany goes green - this slogan stands for a profound transformation of the German society towards more sustainable and climate proof structures. This comprises forceful climate protection measures, which are supplemented by a comprehensive strategy to promote the adaptation to climate change. Further content of this strategy is the nuclear power phase out in the medium term. Further key elements to achieve sustainable structures in the mid or long-term are innovative landscape and regional planning projects. They ensure a consideration ecosystem services in their spatial dimension in decision making processes and contribute to a strengthening of regional identity and economic power. The transformation described is supported by a financial program including incentives, tax reductions, and research funding. Meanwhile the transformation process is triggering positive economic effects. Despite of the success until now, decision makers have to carefully reason about side-effects of the transformation process on hidden or less known aspects.

\section{REFERENCES}

AGEB(2012) Ausgewöhlte Effizienzindikatoren zur Energiebilanz Deutschland [Selected energy efficiency indicators concerning the energy balance in Germany] Berlin[In German].

Budinger, A., and Gruehn, D.(2012) "Increasing land value through open spaces - new options for brownfield redevelopment," $6^{\text {th }}$ annual PLPR-conference "Rights, Responsibilities and Equity in Land Use Planning," 7-10 February 2012 in Belfast, Northern Ireland, 12 p.

EC(2000) Directive 2000/60/EC of the European Parliament and of the Council of 23 October 2000 establishing a framework for Community action in the field of water policy, CELEX-EUR Official Journal L 327, 22 December 2000, p. 1-72.

EC(2001) Directive 2001/42/EC of the European Parliament and of the Council of 27 June 2001 on the assessment of the effects of certain plans and programmes on the environment, Official Journal L 197, 21 July 2001, p. 30-7.

EEC(1985) Council Directive 85/337/EEC of 27 June 1985 on the assessment of the effects of certain public and private projects on the environment.

EEC (1992) Council Directive 92/43/EEC of 21 May 1992 on the conservation of natural habitats and of wild fauna and flora.

Egle, C., Ostheim, T., and Zohlnhöfer, R.(2003) Das rotgrüne Projekt [The project of social democratic and green party] (Wiesbaden: VS Verlag) [In German].

Federal Environment Agency (2011) Übersicht zur Entwicklung der energiebedingten Emissionen in Deutschland 1990-2010 [Development of emissions due to energy in Germany 1990-2010] Dessau[In German].

Federal Environment Agency (2012) Schwerpunkte 2012. Jahrespublikation des Umweltbundesamtes [Focus 2012. Annual report of the German Federal Environment Agency] Dessau[In German].

German Federal Government (2008) Deutsche Anpassungsstrategie an den Klimawandel [German Adaptation to Climate Change Strategy] [In German].

Gerstengarbe, F.W., Badeck, F., Hattermann, F., Krysanova, V., Lahmer, W., Lasch, P., Stock, M., Suckow, F., Wechsung, F., and Werner, P.C.(2003) Studie zur klimatischen Entwicklung im Land Brandenburg bis 2055 und deren Auswirkungen auf den Wasserhaushalt, die Forst- und Landwirtschaft sowie die Ableitung erster Perspektiven [Climate change in Brandenburg until 2055 and ist impact on water balance, agriculture and forestry and the deduction of first perspectives] Potsdam: PIK-Report 83[In German].

GFME - German Federal Ministry for the Environment, Nature Conservation and Nuclear Safety (ed). (2011) Erneuerbare Energien - Innovationen für eine nachhaltige Energiezukunft [Renewable energies - Innovations towards a sustainable future for energy use] Berlin[In German].

GFME - German Federal Ministry for the Environment, Nature Conservation and Nuclear Safety (ed). (2012a) Die Energiewende - Zukunft made in Germany [The energy turn - Future made in Germany] Berlin[In German].

GFME - German Federal Ministry for the Environment, Nature Conservation and Nuclear Safety (ed). (2012b) 


\section{Special Contribution}

Erneuerbare Energien in Zablen - Nationale und internationale Entwicklung [Renewable Energies in Figures - National and international development] Berlin [In German].

GFME and FAN [German Federal Ministry for the Environment, Nature Conservation and Nuclear Safety \& Federal Agency for Nature Conservation] (2012) "Das Grüne Band wird internationaler" ["The green belt becomes more international"] Umwelt 4:711[In German].

Gruehn, D.(2006) "Landscape Planning as a Tool for Sustainable Development of the Territory - German Methodology and Experience," in Vogtmann, H. and Dobretsov, N. (eds.), Environmental Security and Sustainable Land Use - with special reference to Central Asia NATO Security through Science Series, (Heidelberg, Germany:Springer Netherlands) pp. 297 307.

Gruehn, D.(2008) "Challenges in Land Policies to Address Global Warming and Climate Change and to Promote Green Energy," In: Korean Ministry of Land, Transport and Maritime Affairs \& Korean Land Corporation (eds.) Results and Challenges of National Land Development. International Conference for Commemorating the 60th Anniversary of the Republic of Korea - Manuscripts Book (Seoul), pp. 62-73.

Gruehn, D.(2010) "Regional Planning and Projects in the Ruhr Region (Germany)," Conference Proceedings of International Workshop on Sustainable City Region, 24-25 February 2010, Tainan (ROC), pp.118-25.

IPCC - Intergovernmental Panel on Climate Change (2007) Working Group II Report "Impacts, Adaptation and Vulnerability" (Cambridge, UK:Cambridge University Press).

Jacob, D., and Podzun R.(1997) "Sensitivity studies with the regional climate model REMO," Meteorology and Atmospheric Physics 63:119-29.

Köcher, R.(2011) "Eine atemberaubende Wende" ["A breathtaking turn"], Frankfurter Allgemeine Zeitung, 20 April 2011.

Mahammadzadeh, M., and Chrischilles, E.(eds.) (2012) Klimaanpassung als Herausforderung für die Regional-und Stadtplanung [Adaptation to climate change as challenge for regional and urban planning], (Köln: Klimzug Working Paper).
NEP(2012) Netzentwicklungsplan Strom [National electric power system development plan]. available online at http://www.netzentwicklungsplan.de.

PIK - Potsdam Institute for Climate Impact Research (2005) Verbundvorbaben Klimawandel-Auswirkungen, Risiken, Anpassung [Joint research project climate change - Impacts, risks, adaptation] Potsdam.

Rannow, S., Loibl, W., Greiving, S., Gruehn, D., and Meyer, B. (2010) "Potential impacts of climate change in Germany - Identifying regional priorities for adaptation activities in spatial planning," Landscape and Urban Planning 98(3-4):160-71.

Roth, M., and Gruehn, D. (2012) "Visual Landscape Assessment for Large Areas - Using GIS, Internet Surveys and Statistical Methodologies in Participatory Landscape Planning for the Federal State of Mecklenburg-Western Pomerania, Germany," Proceedings of the Latvian Academy of Sciences, Section A: Humanities and Social Sciences 66(3):129-42.

Schasse, U., Gehrke, B., and Ostertag, K. (2012) Ausgerwählte Indikatoren zur Leistungsfähigkeit der deutschen Umwelt- und Klimaschutzwirtschaft im internationalen Vergleich: Produktion, Außenhandel, Umweltforschung und Patente [International comparison of selected performance indicators of the German environmental and climate protection economy: production, foreign trade, environmental research and patents] (Dessau: Federal Environment Agency). [In German]

Simonis, U.(2001) Key Word Environmental Policy. Discussion Paper FS-II 01-403, (Berlin: Wissenschaftszentrum).

Stolte, D. (2010) "Blühende Landschaften - mehr als seine Metapher" ["Flourishing landscapes - more than a metaphor"], Welt am Sonntag, 26 September 2010. [In German]

Ulrich, B. (1995) "The history and possible causes of forest decline in central Europe, with particular attention to the German situation," Environmental Reviews 3(34):262-76.

United Nations (1998) Kyoto Protocol to the United Nations Framework Convention on Climate Change.

Uttke, A., Niemann, L., Schauz, T., and Empting, P.(eds.)(2008) International Building Exbibition Emscher Park. The projects 10 years later (Essen, Germany: Klartext Verlag). 
Weber, M., and Hespelkamp, J. (2005) "Merging Research Perspectives on Innovation Systems and Environmental Innovation: An Introduction," in Weber, M. and Hespelkamp, J. (eds.), Towards Environmental Innovation Systems (Berlin;Heidelberg, Germany: Springer), pp. 1-7.

Zebisch, M., Grothmann, T., Schröter, D., Hasse, C., Fritsch, U., and Cramer, W.(2005) Klimawandel in Deutschland. Vulnerabilität und Anpassungsstrategien klimasensitiver Systeme [Climate change in Germany. Vulnerability and adaptation strategies for climate sensitive systems, (Berlin: UBA-Texte 08/05). [In German] 